\title{
Information that (de)motivate women's decision making on Planned Home Birth
}

\author{
Informações que (des)motivam a tomada de decisão das mulheres pelo Parto Domiciliar Planejado \\ Informaciones que des(motivan) la toma de decisión de las mujeres por el Parto Domiciliario Planeado
}

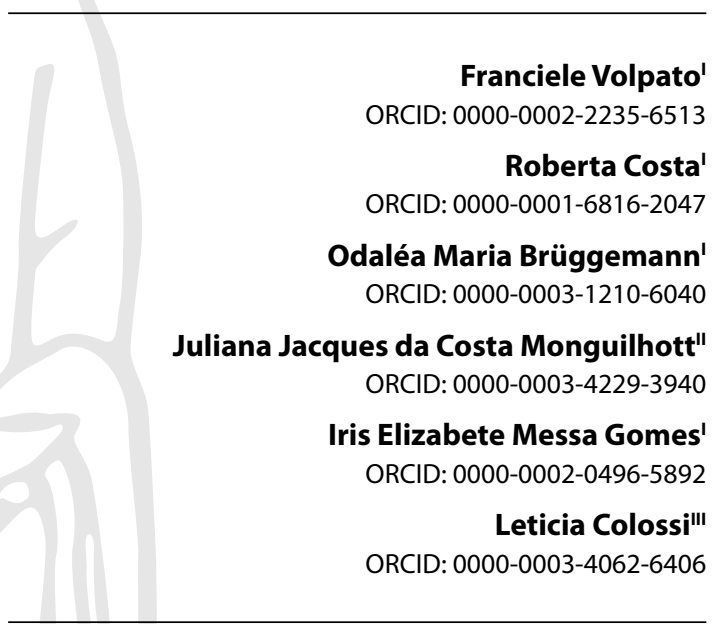

'Universidade Federal de Santa Catarina. Florianópolis, Santa Catarina, Brazil.

"Instituto Federal de Santa Catarina. Florianópolis, Santa Catarina, Brazil. I"Waterford Birth Centre, Hamilton Birth and Post Natal Care. Hamilton, Waikato, New Zealand.

How to cite this article: Volpato F, Costa R, Brüggemann OM, Monguilhott JJC, Gomes IEM, Colossi L. Information that (de)motivate women's decision-making for Planned Home Birth.

Rev Bras Enferm. 2021; 74(4):e20200404.

https://doi.org/10.1590/0034-7167-2020-0404

\section{Corresponding author:}

Franciele Volpato

E-mail: franparteira@gmail.com

EDITOR IN CHIEF: Antonio José de Almeida Filho ASSOCIATE EDITOR: Andrea Bernardes

Submission: $07-21-2020$

Approval: $11-13-2020$

\section{ABSTRACT}

Objective: To understand how information about Planned Home Birth motivates or discourages women's decisions on this location of birth. Method: Descriptive exploratory study, qualitative approach. Data collection carried out from February to April 2019, through semi-structured interviews with 14 women and documentary sources. The data were analyzed using Bardin's content analysis process, with the help of ATLAS.ti 8.0. Results: The motivations for choosing Planned Home Birth are: respect for the autonomy and natural process of childbirth and delivery, support from a partner and trust in professionals. Aspects that discourage this choice are fear of complications, the need for a hospital medical structure, opinions that value risk. Conclusion: Women's choices are based not only on information, but also on how that information is processed. This study demonstrated that the perception pertaining to the safety of Planned Home Birth is essential for making this decision.

Descriptors: Home Birth; Humanized Childbirth; Obstetric; Decision making; Peer Influence; Obstetric Nursing.

\section{RESUMO}

Objetivo: Compreender como as informações sobre o Parto Domiciliar Planejado motivam ou desmotivam a tomada de decisão das mulheres por esse local de parto. Método: Estudo descritivoexploratório, abordagem qualitativa. Coleta de dados realizada de fevereiro a abril de 2019, mediante entrevista semiestruturada com 14 mulheres e fontes documentais. Os dados foram analisados usando-se processo de análise de conteúdo de Bardin, com auxílio do ATLAS.ti 8.0. Resultados: As motivações para escolha pelo Parto Domiciliar Planejado são: respeito à autonomia e processo natural do parto e nascimento, apoio do companheiro e confiança nos profissionais. Aspectos que desmotivam essa escolha são medo de intercorrências, necessidade de estrutura médicohospitalar, opiniões que valorizam o risco. Conclusão: A escolha da mulher não se baseia apenas em informação, mas também no modo de processar essa informação. Este estudo demostrou que a percepção acerca da segurança do Parto Domiciliar Planejado é essencial para a tomada dessa decisão.

Descritores: Parto Domiciliar; Parto Humanizado; Tomada de Decisões; Influência dos Pares; Enfermagem Obstétrica.

\section{RESUMEN}

Objetivo: Comprender como informaciones sobre Parto Domiciliario Planeado motivan o desmotivan la toma de decisión de mujeres por ese local de parto. Método: Estudio descriptivo-exploratorio, abordaje cualitativo. Recogida de datos realizada de febrero a abril de 2019, mediante entrevista semiestructurada con 14 mujeres y fuentes documentales. Datos analizados utilizándose proceso de análisis de contenido de Bardin, con auxilio del ATLAS.ti 8.0. Resultados: Las motivaciones para selección por Parto Domiciliario Planeado son: respecto a la autonomía y proceso natural del parto y nacimiento, apoyo del compañero y confianza en los profesionales. Aspectos que desmotivan esa elección son miedo de intercurrencias, necesidad de estructura médico-hospitalario, opiniones que valoran el riesgo. Conclusión: Elección de la mujer no se basa solo en información, pero también en el modo de procesar esa información. Este estudio demostró que la percepción acerca de la seguridad del Parto Domiciliario Planeado es esencial para la toma de esa decisión.

Descriptores: Parto Domiciliario; Parto Humanizado; Toma de Decisiones; Influencia de las Parejas; Enfermería Obstétrica. 


\section{INTRODUCTION}

The care that women receive during delivery and childbirth is a relevant part of their feminine experience. A positive delivery experience is one that meets or exceeds a woman's expectations, and this includes the birth of a healthy baby, in a safe environment, with continuous technical and emotional support. Such an experience can generate women that are fulfilled with their own delivery and involved with birth decision making ${ }^{(1)}$.

An important and complex decision is directed to the location that offers such care and its association with different aspects related to childbirth ${ }^{(2)}$, which concern the organization of care in each location. While delivery in a hospital environment is organized to meet the needs of the obstetric system and is predominantly assisted by doctors, childbirth in the home environment, however, organizes its assistance in order to respect the needs of the woman and the newborn, in addition to being mostly attended by obstetric professionals or midwifes ${ }^{(3)}$. In this sense, the home is no longer just a different place for birth but is seen in this study as a counter-hegemonic model of care for delivery and childbirth.

In the Brazilian reality, public options for giving birth are limited to hospitals and, in a few places, also to regular birth centers, with hospitals accounting for $98.36 \%$ of births ${ }^{(4)}$. However, some women dissatisfied with the assistance of the hospital care model, also characterized by the excess of unnecessary interventions, have opted for Planned Home Birth (PHB). This, in turn, presents positive maternal and neonatal results, which refer to fewer interventions and morbidity in delivery and birth, in addition to the greater probability of vaginal delivery. Further, the satisfaction of women with the experience of childbirth at home stands out, since, in this place, they feel empowered, in control of their parturition process and satisfied with the quality of care that is offered ${ }^{(5-7)}$.

Considering that hospital births are the norm, women who want another place to give birth have less opportunity to access quality information based on evidence, either through professionals, friends, or the media( ${ }^{(8-9)}$. In the context of prenatal care, this gap harms a fundamental principle of woman-centered care, the informed choice of the place of delivery, which is anchored in the woman's right to receive such information and to be involved in the decision-making process throughout the obstetric care, regardless of their sociodemographic profile ${ }^{(10-13)}$.

Thus, if this limitation were not enough, in the course of choosing the place of birth, women are also individually and collectively affected by cultural and historical associations between birth and security, as well as influenced by narratives that value risk, guilt, and responsibility. In addition, this discourse, is strongly related to the traditional model of care, which in turn is anchored in patriarchal values, restricts women's decisions, and effectively limits the opportunities to plan childbirth in places other than the hospital ${ }^{(14)}$.

In this sense, there are multiple aspects that can contribute for the woman to obtain the confidence necessary to plan and choose where and how to give birth ${ }^{(2)}$. Thus, this study is justified since, although research identifies the reasons why women choose PHB, the reasons and information for this choice are little explored $^{(15-17)}$ and even unknown in the Brazilian context.

\section{OBJECTIVE}

To understand how information about PHB motivates or discourages women's decisions on this location of birth.

\section{METHODS}

\section{Ethical aspects}

After agreeing to participate in the study, the women signed the Termo de Consentimento Livre e Esclarecido [Free and Informed Consent Form], provided for in Resolution CNS-466/2012 ${ }^{(18)}$, ensuring the anonymity and confidentiality of information through the use of an alphanumeric code (E1 to E14).

The study was carried out after approval by the Comitê de Ética em Pesquisa com Seres Humanos (CEPSH) [Ethics Committee in Research with Human Beings] of the Universidade Federal de Santa Catarina (UFSC) [Federal University of Santa Catarina], regarding its ethical and legal aspects.

\section{Study type}

The methodology chosen for this study is of a descriptiveexploratory nature, with a qualitative approach. The description of the investigative process was based on the Consolidated Criteria for Reporting Qualitative Research (COREQ).

\section{Study scenario}

The context of this study was the assistance provided by the teams that attend PHB in the state of Santa Catarina, since this was the starting point for capturing the women who showed interest in obtaining more information about this option as a birth location.

The teams that attend PHB find support in the Associação Brasileira de Enfermeiros Obstetras, Neonatais e Obstetrizes do Estado de Santa Catarina (ABENFO) [Brazilian Association of Obstetric, Neonatal, and Midwifery Nurses of the State of Santa Catarina], which, through the PHB Commission, has acted in favor of this option. In 2016, with COREN, it formulated the first Technical Opinion (No. 23) nationally to guide obstetric nursing regarding some criteria and conduct on $\mathrm{PHB}$.

PHB in the state is a private financing option, which is little discussed with women as an option and lacks a voicing with the women and newborns health care network. Despite this, the number of professionals who attend PHB grows and, thus, the possibilities of choice for some women expand.

\section{Data source}

The selection of participants occurred through contact with professionals who attend PHB, work with the humanization of childbirth and delivery, as well as through the personal network of one of the researchers who worked in this scenario. The professionals were informed about the objectives of the study and were invited to suggest women who met the inclusion criteria, namely: women after the $30^{\text {th }}$ postpartum day, who showed interest in $\mathrm{PHB}$ during prenatal care, regardless of the outcome of the birth location, residing in Santa Catarina; Women under 18 years of age 
and/or who had given birth over the period of one year from the day of the interview, were excluded in order to minimize potential memory loss due to the time elapsed since the birth experience.

Some professionals who knew eligible women provided their telephone details via Whatsapp ${ }^{\circledast}$. Others sent an invitation that was written by the researchers to email lists and Whatsapp ${ }^{\circledR}$ groups, which contained the objectives of the research and the inclusion criteria, so that women interested in participating in the study could volunteer. Through these invitations, 7 women replied expressing their interest in the research and another 17 were contacted by phone and invited to participate. Of the latter, two did not call back, and one withdrew herself due to personal reasons. The number of participants was determined by means of saturation sampling, that is, when the certainty prevailed that, even provisionally, the logic of the object of the study was found in all its connections and interconnections ${ }^{(19)}$. The final sample, therefore, was composed of 14 women.

\section{Data collection and organization}

Data collection was carried out by one of the researchers, from February to April 2019, through semi-structured, audio-recorded interviews, lasting approximately one hour. The question "What information regarding $\mathrm{PHB}$ did you receive during the decisionmaking process pertaining to the place of delivery?" guided the interview. In addition, documents provided by the interviewees were also analyzed (service contract with the team, free and informed consent form, guidelines on PHB). The interviews took place at the interviewees preferred locations and were previously scheduled. Thus, nine interviews were conducted in person at the women's residence and, five others, via Whatsapp ${ }^{\circledR}$ video calls with the presence of the babies in most of them.

Before the recording started, the participants were informed about the objectives of the study and answered the questions regarding the sociodemographic and obstetric characterization. At the end of the interviews, the women were asked whether they received any material with information on $\mathrm{PHB}$; if so, they were asked for a copy. All interviews were transcribed and validated by the participants, with only one interview being adjusted in terms of content.

\section{Data analysis}

Data analysis took place through Bardin's content analysis process, organized in three stages: pre-analysis; material exploration; treatment of results, inference, and interpretation ${ }^{(20)}$. The software ATLAS.ti 8.0 was used to help organize the data, which started with the creation of a project consisting of 26 documents: 14 interviews and 12 materials made available by the interviewees (service provision contracts, consent terms, guidelines).

In four stages, the data were organized: floating reading; selection of relevant and representative elements; elaboration of hypotheses/objectives and reference of indexes; and elaboration of indicators. With the help of ATLAS.ti 8.0, the relevant sections of the interviews (citations) were selected to meet the objective of the study. Then, the material was explored, which essentially consisted of coding operations, correlating the statements that had the same meaning to categorize them.
The last phase concerns the treatment of the results obtained, inference and interpretation, so that they become meaningful and valid. After the entire analysis process, the data gave rise to two categories: Influences that motivate the choice for PHB; and Influences that discourage the choice for PHB.

\section{RESULTS}

The study participants were between 24 and 38 years old and were in a stable relationship when they chose the place of birth. One of them had a high school degree, and the others had a university degree, most with postgraduate degrees. They were residents of Florianópolis, Joinville, and Chapecó, in the state of Santa Catarina. Only one woman performed her prenatal care exclusively on the public network. Nine women had birth assistance in the private network; the others, in the public network. Regarding the obstetric history, 11 were primiparous, and 3 had a previous cesarean section. Of the 14 women, 10 experienced vaginal delivery, 5 of them at home, and the others evolved to cesarean section.

Women reported several reasons that affect the choice for $\mathrm{PHB}$, among which are personal aspects related to the socio-cultural context. Here, the information was categorized as motivations or aspects that discourage PHB.

\section{Category I - Motivations for choosing Planned Home Birth}

Women related home birth to autonomy, protagonism, and freedom. Home birth is understood by them as one without unnecessary interventions and with respect to the natural process:

[...] I thought that the woman gave herself more at home, that she was better supported, that nature expresses itself better, and that without interventions childbirth can follow its course in a better way. (E12)

In addition, at home they can be accompanied by the people of their choice and experience a delivery with individual, exclusive attention. These and other aspects were responsible for the security that women expressed feeling about the home environment:

So, home birth makes me safe for that, because I'm in my own little corner, with the people I wish were there and that I would have a little more intimacy to say "no, not now, wait a little while", You know? That's what I think security is. (E11)

[...] the respect for my rhythm, that is, respect for the organic process of childbirth, this, for me, is security.(E9)

All women received support from their partners when making decisions about the place of delivery. This support was characterized by shared decision, engaging in the decision-making process, or by respecting the woman's choice:

[...] my partner always supported me a lot. He really left that decision to me. He told me to choose where I felt best. That he would support me no matter what, if it were at the hospital, if it was at home. That was a decision for me, for my feelings, for my thoughts. (E4) 
Another important motivation was women who had successful childbirth experiences:

[...] my mother [...] and my whole family, as much as they didn't know [home] delivery, they have this very beautiful memory of birth [...] I sent a video to my mother, she saw it and she didn't doubt it anymore. (E4)

The women also related the experience of the professionals who would attend the birth at home, with security for the monitoring process:

The team's experience was a very strong contributor [...] they reported a lot of experience and that gave me a lot of assurance, even to not worry so much about the safety items they had, because I knew I was, I was in their hands, I was good, well-guarded, I was in good hands. (E10)

Thus, the information shared with professionals about the management of complications at home and the ability to identify potential need for transferring them to the hospital reassured the women:

So as soon as the team gave me this security, you know, that there was able time to get to the hospital, but until that happens, we would be able to realize it, we will have the feeling of it, we will identify that it is not working and go to the hospital [...]. I knew that if there was something that couldn't be resolved here, there would be time to get to the hospital and I wouldn't die in 20 minutes, like this, bleeding like this. (E14)

[...] she would bring some equipment, like, oxygen, she would have it, and in case the baby was born with a problem she would have some equipment that she would be able to solve at home [...] for some other issues, we would have to go to the hospital [...]. (E6)

Another point that motivates women in deciding the location of delivery in a second pregnancy is a previous traumatic hospital birth experience, which was marked by obstetric violence. In this way, they report the desire to live a different experience at home as a form of overcoming the previous one:

Because the issue of childbirth was always there, you know, because somehow it was something I was looking for, a cure, you know, from this experience I had with the first delivery [...] my only fear was having to go to the hospital. (E9)

[...] So, it was actually an accomplishment and an overcoming also in relation to the previous birth [...] it came from doing something completely different from what had been my previous experience and... that was what attracted me the most. (E10)

\section{Category II - Aspects that discourage the choice for Planned Home Birth}

The women express fear of having complications at home, especially related to the baby:

[...] these are the things that most concern the mother, at least that was what worried me: what if the baby is born and needs some apparatus, some tool that we do not have here at home? (E14)
Also, the uncertainty of arriving at the hospital in a timely manner in case of complications was noted in the speech of the women when it came to the possibility of transfer:

[...] I was afraid of how I would be referred to a maternity hospital if I eventually needed to [...] if the team was prepared for this and what would the care be like. (E10)

[...] just the thought that there might not be enough time to save [my son] or myself [...] some complication happens and we have to go but there is not enough time. I was afraid of that [...]. (E14)

Another issue related to home care during delivery and birth is related to the need for equipment that would only be available in hospitals/maternity hospitals. In the same sense, there is the need for the presence of medical professionals in the context of birth, which is associated with the feeling of security:

[...] if anything happens, I'm at home and I don't have a doctor. It's a fear. I think it's the first feeling that comes. (E2)

[...] If there is a complication or emergency, there are fewer therapeutic possibilities available at home than there would be in a hospital environment, including some that can save lives, such as a blood bank and immediate surgery. (TCLE team X)

It is also worth noting that some people from these women's daily social circle (family members, health professionals, friends) consider the PHB choice to be risky:

[...] my mother, my mother-in-law, my grandmother, everyone was very afraid of home birth. They thought I was doing something crazy, that I was being inconsequential, everything (E7).

[...] my daughter's pediatrician [...] he said: "look, you do what you want, but I don't support it". And then, it moved me a lot when he told me that. That he was like... "oh, I think it's very dangerous" [...] (E2)

[...] People came with the opinion of "oh, that's dangerous" [...] It is my decision and I think a lot of people give up due to this [...] because when you make a decision like that, with a family against it, it is on more factor that you have to deal with, right? (E8)

Finally, another discouraging factor for the choice of women for $\mathrm{PHB}$ is the (im)possibility of paying for this service. Half of the interviewees considered this investment to be very high, outside the financial reality of most families. For these women, regarding PHB: either it is no longer an option, they contract debt, or ask for help from their support network. The discomfort of having to pay for a service that could be offered by SUS [Brazilian Unified Health System] is also manifested by women:

[...] It is very expensive for you to give birth with most teams, this is tragic. Because most people will not have any access at all. (E8)

[...] we did it because my mother-in-law offered to pay [...] if it weren't for that, I don't know if I could have this, the birth I dreamed of [...]. (E10) 


\section{DISCUSSION}

The results of this study allowed us to understand how information influences women in decision making for PHB. This is because they do not make choices in isolation, but in a socially constructed process, influenced by interpersonal relationships and the context or scenario in which they occur ${ }^{(21-22)}$. The participants in this study have in common with women who choose home birth the fact that they are married or live with partners, live in large centers, are over 30 years old, and have a high level of education ${ }^{(22-23)}$, characteristics that suggest easy access to quality information.

Based on the motivations that lead to the decision for PHB, the participants reported reasons for choosing home birth that were similar to other studies: respect for the physiological process of childbirth, autonomy, protagonism, confidence in the birth process, and participation of family members ${ }^{(2,23-26)}$. These benefits linked to PHB sometimes appeared in the voice of women who experienced childbirth in a positive way and became supporters of this birth location ${ }^{(7)}$.

This familiar, intimate, and respectful scenario becomes synonymous with security for women (E11 and E9), as a relationship of trust is built with the team that provides assistance. In contrast, the hospital becomes a threat because it has high rates of interventions - less than $6 \%$ of births are natural — and due to disrespect for good practices in delivery and childbirth ${ }^{(27)}$. PHB has been associated with significantly lower rates of obstetric interventions, higher rates of spontaneous vaginal delivery, lower rates of maternal morbidity, and high satisfaction rates related to the fact that the home environment is more comfortable and offers more participation in the parturitive experience ${ }^{(2,28-29)}$.

Likewise, those participants who had negative experiences in the hospital environment (E9 and E10) have sufficient justifications for not wanting to re-experience this care model. The PHB, then, becomes an alternative to avoid obstetric violence and cascade interventions, characteristics of the hegemonic model. Corroborating these findings, international studies carried out in Australia ${ }^{(30)}$ and the United Kingdom ${ }^{(31)}$ on the motivations for choosing PHB point out that an approach to medicalized care, with routine interventions, contributed to women's lack of satisfaction and to search for other possibilities of birth locations in subsequent pregnancies. Another piece of evidence, therefore, that invites the traditional model to revisit its care practices and philosophy.

During decision making, the baby's partner/father assumes an important position as a motivator ${ }^{(6,32)}$, playing a significant role in decision making, as his support allows the woman to feel confident in choosing the place of delivery, as reported by E4. As a relational being, the mother's decision will not be isolated or independent. This is because her decisions are made in relation to others and alongside them, whether family, friend, or professional ${ }^{(33)}$. That is, when the woman chooses the location of birth, several factors of the socio-cultural context in which she lives are influencing this decision. Thus, talking about her interests allows her to add information so that she can assertively choose the place of birth ${ }^{(32)}$.

Another element that motivates the choice for PHB is the confidence built in the relationship with the professionals who will attend home birth. In the present study, this trust is based on professional competence and information sharing. It is worth mentioning that, in Brazil, PHB is generally assisted by obstetric/ midwife nurses ${ }^{(4,23)}$, who work in favor of reducing unnecessary procedures, promoting the quality of care, and consequent women's satisfaction $^{(34)}$.

In this context, the evidence demonstrates that women accompanied by their midwives felt supported by them, in a relationship of trust ${ }^{(30,35-36)}$, which is different from the hegemonic model of hospital care, since it is performed by professionals unknown to that woman. Women want a childbirth experience with kind, sensitive professionals, who understand their beliefs, values, and care rituals, as well as offering safety and technical competence ${ }^{(22,26)}$.

In this way, information that motivates the decision making for $\mathrm{PHB}$ is related to the benefits that women recognize in this care model, as well as the support they find in their partners, and the trust built in the relationship with the professionals who attend this birth location. Therefore, the development of a trusting relationship between the woman and the professionals can generate mutual responsibility in decision making. In other words, both become active in the informed choice process, minimizing the hierarchy in the relationship, and respecting the woman's autonomy ${ }^{(11,37)}$.

On the other hand, there is information that discourages the option for $\mathrm{PHB}$, which is strongly marked by the current hegemonic care model, centered on the risk and mechanization of childbirth. In this scenario, where the focus is on unfavorable outcomes, the fear that complications will happen, especially with the baby, is a limiting factor for giving birth at home. This is because women's perceptions about the nature of the birth process are important to determine the choices in relation to childbirth ${ }^{(38)}$.

Thus, the professional, again, plays an important role during prenatal care by informing the woman about the most prevalent complications during childbirth and birth at home ${ }^{(39)}$. However, the professional should also provide and discuss scientific evidence that points out the frequency and handling of these complications, preferably comparing them to the hospital environment and relativizing them using data from the country where the birth will take place.

In the Brazilian scenario, however, the few studies on the neonatal results of $\mathrm{PHB}^{(3,5,40)}$ suggest that the respect for the physiology of childbirth and the restricted use of interventions in this type of birth method may have been responsible for the absence of complications in deliveries and home births ${ }^{(41)}$. This question is in line with an important meta-analysis of international studies, which included studies in countries that have well integrated home births and little integrated into the obstetric care network, and the risk of perinatal or neonatal mortality was no different when the delivery was planned at home or at the hospital ${ }^{(42)}$. All studies included only women with common risk pregnancies.

Even though the Brazilian Ministry of Health recognizes the home as a possible place for delivery/birth ${ }^{(4)}$, PHB does not have a formalized referral flow, being considered to be poorly integrated into the network ${ }^{(23)}$. This information is relevant in the decision-making process of women, as different studies show that the perinatal and 
neonatal results of home births are related to the transfer conditions ${ }^{(6,28,38)}$. In addition, even higher transfer rates are observed in places where PHB is further integrated into the health system, suggesting that good integration may be associated with timely access and better care in case of intrapartum complications ${ }^{(42)}$.

However, the choice of women is based not only on information, but also on the way in which they process that information. This is linked to their experience, to the socio-cultural and political context, to the concept of security ${ }^{(22)}$. In this context, it is considered that the safety of the baby and the woman herself is a key point in making decisions pertaining to the place of birth ${ }^{(25,35)}$.

Safety, however, is linked to the construction of risk that is related to birth. In this study, the women and the documents offered by the teams that attend PHB (TCLE team X) point to the possible need for equipment and the medical professional linked to the hospital environment and the guarantee of safety. The biomedical model of care, likewise, has cultivated the idea that devices, doctors, and institutions offer the best delivery assistance. Thus, conceiving that hospital delivery also carries its set of risks means opposing the norm, which is ingrained in today's culture.

In this context, to consider the delivery at home and sharing this possibility with society presented itself as an influence that discourages the choice for PHB. The need that each person attaches to the moment of birth, anchored in their cultural values, is a tool to judge the woman who understands that home offers sufficient security for her and her baby. Thus, women's autonomy is undermined by personal criticisms, based on isolated experiences and by the dominance of the technocratic model of childbirth care. And so, women experience the antagonism between what they want and what society considers correct and safe ${ }^{(21)}$. In addition to these issues, an English study attributed the lack of consistent and comprehensive information about the options for birth locations, as well as the lack of information about the implications of giving birth at home, as possible reasons for home birth to be neglected ${ }^{(9)}$. This is because only $2.1 \%$ of women in the United Kingdom in $2018^{(43)}$ decided on home birth, even though it was recommended for women of habitual obstetric risk during the decision-making process.

Finally, the participants in this study recognize that having to pay for home birth becomes costly and not accessible to all. In the Brazilian context, $\mathrm{PHB}$ is a restricted possibility, considering that it is not part of public policy and is a choice that is emotionally and financially supported by women. This situation weakens the assistance to women, as well as the professionals who care at home, since this option is not public nor is it part of the referral and counter-referral system, a situation that can jeopardize the guarantee of continuity of care in the face of the need for transfer. In this way, it affects determinant and conditioning aspects of quality of life that act in the social dimension and are related to health promotion and protection ${ }^{(44)}$.

Therefore, to actively decide on the place of delivery, it is important for the woman to identify the reasons that are presented to her and how they affect her choice. This way, she will be able to reflect on these reasons, allowing them or not to interfere in her decision. She will have to look at herself and consider her values, define security, identify which risks she is willing to accept and how they could be managed ${ }^{(45)}$.

\section{Study limitations}

As limitations of the study, we highlight the difficulty of finding women who intended on PHB but gave up on this option.

\section{Contributions to the field of Nursing, Health, or Public Policy}

In Brazil, there are few options for delivery locations outside the hospital environment that are part of the public health network, nor is it a policy that encourages the choice of women for the place of delivery. Thus, this study contributes to the obstetric scenario by revealing information about PHB that can be problematized in the course of decision-making for the model of delivery and childbirth care.

\section{FINAL CONSIDERATIONS}

Both women's testimony and the analyzed documents allowed us to understand that the woman's decision making in favor of $\mathrm{PHB}$ is influenced by information that motivates or discourages this choice. However, the desire for a safe delivery for both the woman and the newborn permeates all influences. Obstetric care that respects the physiology of childbirth and ensures quality information in the relationship between the woman and the professional stands out as a motivation for choosing PHB.

In contrast, the information that supports the fear of unfavorable outcomes, anchored in the model centered on risk and mechanization of childbirth, stands out as reasons that discourage the choice of home as a location of birth. Also, there is an access restriction to $\mathrm{PHB}$, since it is not included in the public policy of maternal and childcare in Brazil and it becomes costly for women. In addition, the absence of the State to recognize it and make it available as a possibility of choice, makes PHB disintegrated from the delivery and childbirth assistance network, a fact that compromises transfers (emergency or not) due to the opportune time of commuting and care, or the lack of continuity of care by the same professionals.

Bearing in mind that the woman's choice for the place of birth is not isolated, but it happens through information and influences from the context in which she experiences this choice, discussing the security of PHB in the Brazilian scenario is essential to optimize decision making. Thus, it allows the woman to combine the care offered at home with her perceptions and values related to birth and can consciously choose the place of birth.

\section{FUNDING}

This study received funding from the Conselho Nacional de Desenvolvimento Científico e Tecnológico (CNPq) [National Council for Scientific and Technological Development] through a research grant. 


\section{REFERENCES}

1. World Health Organization (WHO). Recommendations: intrapartum care for a positive childbirth experience [Internet]. 2018 [cited 2020 Jun 13]. Available from: https://www.who.int/reproductivehealth/publications/intrapartum-care-guidelines/en/

2. Zielinski R, Ackerson K, Kane-Low L. Planned home birth: benefits, risks, and opportunities. Int J Women's Health. 2015;7:361-77. https://doi. org/10.2147/IJWH.S55561

3. Koettker JG, Bruggemann OM, Dufloth RM, Monticelli M, Knobel R. Comparação de resultados obstétricos e neonatais entre primíparas e multíparas assistidas no domicílio. Cienc Enferm. 2015;21(2):113-25. https://doi.org/10.4067/S0717-95532015000200011

4. Ministério da Saúde (BR). Secretaria de Ciência, Tecnologia e Insumos Energéticos. Diretriz nacional de assistência ao parto normal: relatório de recomendação [Internet]. Comissão Nacional de Incorporação de Tecnologias no SUS. Brasília: Ministério da Saúde. 2016 [cited 2019 Jul 10]. Available from: http://bvsms.saude.gov.br/bvs/publicacoes/diretrizes_nacionais_assistencia_parto_normal.pdf

5. Koettker JG, Bruggemann OM, Dufloth RM, Knobel R, Monticelli M. Outcomes of planned home birth assisted by nurses, from 2005 to 2009 , in Florianópolis, Brazil. Rev Saúde Pública. 2012;46(4):747-50. https://doi.org/10.1590/S0034-89102012005000051

6. Scarf VL, Rossiter C, Vedam S, Dahlen HG, Ellwood D, Forster D, et al. Maternal and perinatal outcomes by planned place of birth among women with low-risk pregnancies in high-income countries: a systematic review and meta-analysis. Midwifery. 2018;62:240-55. https://doi. org/10.1016/j.midw.2018.03.024

7. Leon-Larios F, Nuno-Aguilar C, Rocca-Ihenacho L, Castro-Cardona F, Escuriet R. Challenging the status quo: women's experiences of opting for a home birth in Andalucia, Spain. Midwifery. 2019;70:15-21. https://doi.org/10.1016/j.midw.2018.12.001

8. Medeiros RMK, Santos IMM, Silva LR. A escolha pelo parto domiciliar: história de vida de mulheres que vivenciaram esta experiência. Esc Anna Nery [Internet]. 2008 [cited 2020 Apr 26];12(4):765-72. Available from: https://www.redalyc.org/articulo.oa?id=127715323022

9. Smith JN, Taylor B, Shaw K, Hewison A, Kenyon S. 'I didn't think you were allowed that, they didn't mention that': a qualitative study exploring women's perceptions of home birth. BMC Pregnancy Childbirth. 2018;18(1):105-16. https://doi.org/10.1186/s12884-018-1733-1

10. Mcara-Couper J, Jones M, Smythe L. Caesarean-section, my body, my choice: the construction of 'informed choice' in relation to intervention in childbirth. Fem Psychol. 2011;22(1):81-97. https://doi.org/10.1177/0959353511424369

11. Handa M, Sharpe MD. Shifting paradigms in women's health care: from informed consent to informed choice. Women Health Bull. 2015;2(2):e60213. https://doi.org/10.17795/whb-28194

12. College of Midwives of Ontário. Place of birth handbook [Internet]. 2015 [cited 2020 Apr 26]. Available from: https://www.cmbc.bc.ca/wpcontent/uploads/2017/10/Place-of-Birth-Handbook.pdf

13. Association of Ontário Midwives. Choice of birthplace. Guideline for discussing choice of birthplace with clients. Ontario [Internet] 2016 [cited 2020 Apr 26]. Available from: http://www.cmo.on.ca/wp-content/uploads/2015/07/AOM-Guideline-on-Choice-of-Birthplace.pdf

14. Coxon K, Sandall J, Fulop NJ. To what extent are women free to choose where to give birth? how discourses of risk, blame and responsibility influence birth place decisions. Health Risk Soc. 2013;16(1):51-67. https://doi.org/10.1080/13698575.2013.859231

15. Catling-Paull C, Coddington RL, Foureur MJ, Homer CSE. Publicly funded homebirth in Australia: a review of maternal and neonatal outcomes over 6 years. Med J Australia. 2013;198(11):616-20. https://doi.org/10.5694/mja12.11665

16. Coxon K, Chisholm A, Malouf R, Rower R, Hollowell J. What influences birth place preferences, choices and decision-making amongst healthy women with straightforward pregnancies in the UK? A qualitative evidence synthesis using a 'best fit' framework approach. BMC Pregnancy Childbirth. 2017;17(1):103. https://doi.org/10.1186/s12884-017-1279-7

17. Meredith $\mathrm{D}$, Hugill K. Motivations and influences acting on women choosing a homebirth: seeking a 'cwtch' birth setting. Br J Midwifery. 2017;25(1):10-16. https://doi.org/10.12968/bjom.2017.25.1.10

18. Ministério da Saúde (BR). Resolução n 466/12, de 12 de dezembro de 2012. Dispõe sobre pesquisa envolvendo seres humanos. Brasília: Ministério da Saúde [Internet] 2012 [cited 2019 Sep 08]. Available from: https://bvsms.saude.gov.br/bvs/saudelegis/cns/2013/ res0466_12_12_2012.html

19. Minayo MC. Amostragem e saturação em pesquisa qualitativa: consensos e controvérsias. Rev Pesqui Qualit [Internet]. 2017 [cited 2020 Apr 26];5(7):1-12. Available from: https://editora.sepq.org.br/index.php/rpq/article/view/82/59

20. Bardin L. Análise de conteúdo. 6. ed. São Paulo: Edições 70;2011. 229 p.

21. O'brien D, Casey M, Butler MM. Women's experiences of exercising informed choices as expressed through their sense of self and relationships with others in Ireland: a participatory action research study. Midwifery. 2018;65:58-66. https://doi.org/10.1016/j.midw.2018.07.006

22. Downe S, Finlayson K, Oladapo OT, Bonet M, Gulmezoglu AM. What matters to women during childbirth: a systematic qualitative review. PLos ONE. 2018;13(4):e0194906. https://doi.org/10.1371/journal.pone.0194906

23. Koettker JG, Bruggemann OM, Freitas PF, Riesco MLG, Costa R. Obstetric practices in planned home births assisted in Brazil. Rev Esc Enferm USP. 2018;52:e03371. https://doi.org/10.1590/s1980-220x2017034003371

24. Walker JJ. Planned home birth. Best Pract Res, Clin Obstetr Gynaecol. 2017;43:76-86. https://doi.org/10.1016/j.bpobgyn.2017.06.001 
25. Grigg CP, Tracy SK, Schmied V, Daellenbach R, Kensington M. Women's birthplace decision-making, the role of confidence: part of the evaluating maternity units study, New Zealand. Midwifery. 2015;31(6):597-605. https://doi.org/10.1016/j.midw.2015.02.006

26. Collaço VS, Santos EKA, Souza KV, Alves HV, Zampieri MF, Gregório VRP. The meaning assigned by couples to planned home birth supported by nurse midwives of the Hanami team. Texto Contexto Enferm. 2017;26(2):e6030015. https://doi.org/10.1590/0104-07072017006030015

27. Leal MC, Pereira APE, Domingues RMSM, Filha MMT, Dias MAB, Nakamura-Pereira M, et al. Obstetric interventions during labor and childbirth in Brazilian low-risk women. Cad Saúde Pública. 2014;30(suppl 1):S1-S31. https://doi.org/10.1590/0102-311X00151513

28. Hutton EK, Cappelletti A, Reitsma AH, Simioni J, Home J, Mcgregor C, et al. Outcomes associated with planned place of birth among women with low-risk pregnancies. CMAJ. 2016;188(5):E80-E90. https://doi.org/10.1503/cmaj.150564

29. Davies-Tuck ML, Wallace EM, Davey M, Veitch V, Oats J. Planned private homebirth in Victoria 2000-2015: a retrospective cohort study of Victorian perinatal data. BMC Pregnancy Childbirth. 2018;18(357):1-8. https://doi.org/10.1186/s12884-018-1996-6

30. Catling C, Dahlen H, Homer CS. The influences on women who choose publicly-funded home birth in Australia. Midwifery. 2014;30(7):892-8. https://doi.org/10.1016/j.midw.2014.03.003

31. Feeeley C, Thonsom G. Why do some women choose to freebirth in the UK? an interpretative phenomenological study. BMC Pregnancy Childbirth. 2016;16(59). https://doi.org/10.1186/s12884-016-0847-6

32. Martínez-Mollá T, Solano Ruiz C, Siles González J, Sánchez-Peralvo M, Méndez-Pérez G. The father's decision making in home birth. Invest Educ Enferm. 2015;33(3):573-83. https://doi.org/10.17533/udea.iee.v33n3a22

33. Osuji PI. Relational autonomy in informed consent (RAIC) as an ethics of care approach to the concept of informed consent. Med Health Care Philos. 2017;21(1):101-11. https://doi.org/10.1007/s11019-017-9789-7

34. Sandall J, Soltani H, Gates S, Shennan A, Devane D. Midwife-led continuity models versus other models of care for chilbearing woman: review. Cochrane Database Syst Rev. 2016;4:CD004667. https://doi.org/10.1002/14651858.CD004667.pub5

35. Murray-Davis B, Mcdonald H, Rietsma A, Coubrough M, Hutton E. Deciding on home or hospital birth: results of the Ontario choice of birthplace survey. Midwifery. 2014;30(7):869-76. https://doi.org/10.1016/j.midw.2014.01.008

36. Forster DA, McKay H, Davey MA, Small R, Cullinane F, Newton M, et al. Women's views and experiences of publicly-funded homebirth programs in Victoria, Australia: a cross-sectional survey. Women Birth. 2019;32(3):221-30. https://doi.org/10.1016/j.wombi.2018.07.019

37. Charles S. Attunement and involvement: how expert nurses support patient autonomy. Int J Fem Approach Bioeth. 2017;10(1):175-93. https://doi.org/10.3138/ijfab.10.1.175

38. Preis H, Gozlan M, Dan U, Benyamini Y. A quantitative investigation into women's basic beliefs about birth and planned birth choices. Midwifery. 2018;63:46-51. https://doi.org/10.1016/j.midw.2018.05.002

39. Hildingsson I, Rubertsson C, Karlstrom A, Haines H. A known midwife can make a difference for women with fear of childbirth- birth outcome and women's experiences of intrapartum care. BMJ Sexual Reproduct Healthcare. 2019;21:33-38. https://doi.org/10.1016/j. srhc.2019.06.004

40. Colacioppo PM, Koiffman MD, Riesco MLG, Schneck CA, Osava RH. Parto domiciliar planejado: resultados maternos e neonatais. Rev Enf Ref [Internet]. 2010 [cited 2020 Apr 26];SerllI(2):81-90. Available from: http://www.scielo.mec.pt/pdf/ref/vserllln2/serllln2a09.pdf

41. Koettker JG, Bruggemann OM, Knobel R. Maternal results from planned home births assisted by nurses from the Hanami team in the South of Brazil, 2002 - 2012. Texto Contexto Enferm. 2017;26(1):e3110015. https://doi.org/10.1590/0104-07072017003110015

42. Hutton EK, Reitsma A, Simioni J, Bruton G, Kaufman K. Perinatal or neonatal mortality among women who intend at the onset of labour to give birth at home compared to women of low obstetrical risk who intend to give birth in hospital: a systematic review and meta-analyses. EClin Med. 2019;14:59-70. https://doi.org/10.1016/j.eclinm.2019.07.005

43. Office for National Statistics. Birth characteristics in England and Wales: 2018 [Internet]. 2020 [cited 2020 Jun 08]. Available from: https:// www.ons.gov.uk/peoplepopulationandcommunity/birthsdeathsandmarriages/livebirths/datasets/birthcharacteristicsinenglandandwales

44. Porto D, Garrafa V. A influência da Reforma Sanitária na construção das bioéticas brasileiras. Ciênc Saúde Coletiva. 2011;16(suppl 1):719-29. https://doi.org/10.1590/S1413-81232011000700002

45. Charles $\mathrm{S}$, Wolf AB. Whose values? whose risk? exploring decision making about trial of labor after cesarean. J Med Humanit. 2018;39(2):15164. https://doi.org/10.1007/s10912-016-9410-8 